\title{
High-efficiency Ethanol Yield from Anaerobic Fermentation of Organic Wastes via Stimulating Growth of Ethanol-producing Fe(III)-reducing Bacteria with Magnetite
}

\section{Authors:}

Yang $\mathrm{Li}^{\mathrm{a}}$, Zhiqiang $\mathrm{Zhao}^{\mathrm{b}}$, Qilin $\mathrm{Yu}^{\mathrm{b}}$, Cheng Sun ${ }^{\mathrm{b}}$, Mingwei Wang ${ }^{\mathrm{b}}$ and Yaobin Zhang ${ }^{\mathrm{b}, *}$

\section{Affiliations:}

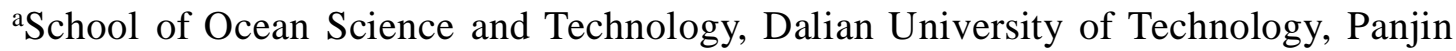
124221, Liaoning, China.

${ }^{\mathrm{b}}$ Key Laboratory of Industrial Ecology and Environmental Engineering (Dalian University of Technology), Ministry of Education, School of Environmental Science and Technology, Dalian University of Technology, Dalian 116024, China.

* Correspondence: Tel: +86 4118470 6460, Fax: +86 41184706263 ;

E-mail address: zhangyb@dlut.edu.cn. 


\section{Materials and Methods.}

Composition of Dairy Wastes. glucose, $19.20 \mathrm{~g}$; yeast extract, $3.84 \mathrm{~g}$; milk powder (Songhuajiang; Taobao.com; China), $16.00 \mathrm{~g}$; NH $4 \mathrm{Cl}, 3.68 \mathrm{~g}$; $\mathrm{KH}_{2} \mathrm{PO} 4,0.80$ $\mathrm{g} ; \mathrm{NaHCO}_{3}, 20.00 \mathrm{~g}$; trace element solution, $10 \mathrm{ml}$; vitamin solution, $10 \mathrm{ml}$.

SEM. Before SEM analysis, the sludge was initially immobilized in a $2.5 \%$ glutaraldehyde solution, dehydrated in graded water-ethanol solutions, then lyophilized and sputter-coated with gold. The operating conditions were as follows: Accelerating voltage was $5000 \mathrm{~V}$; Emission current was 3.9-4.9 uA; Working distance was 9.0-9.3 $\mathrm{mm}$.

DNA Extraction and PCR Amplification. DNA extraction was performed by the E.Z.N.A. Soil DNA Kit. PCR amplification was conducted with the primer pairs 515F (5'-barcode- GTGCCAGCMGCCGCGG-3') and 907R (5'-CCGTCAATTCMTTTRAGTTT-3'), which targeted the V4-V5 region of the bacterial $16 \mathrm{~S}$ rRNA gene. PCR was carried out in a $20 \mathrm{uL}$ solution containing $2 \mathrm{uL}$ of $2.5 \mathrm{mM}$ dNTPs, $0.4 \mathrm{uL}$ of FastPfu Polymerase, $0.8 \mathrm{uL}$ of each primer $(5 \mathrm{uM}), 4 \mathrm{uL}$ of $5 \times$ FastPfu Buffer and $10 \mathrm{ng}$ of template DNA. PCR conditions were as follows: $95^{\circ} \mathrm{C}$ for $2 \mathrm{~min}, 95^{\circ} \mathrm{C}$ for $30 \mathrm{~s}$ repeated 25 cycles, $55^{\circ} \mathrm{C}$ for $30 \mathrm{~s}, 72^{\circ} \mathrm{C}$ for $30 \mathrm{~s}$ and a final extension at $72^{\circ} \mathrm{C}$ for $5 \mathrm{~min}$.

FISH Fixation and Hybridization. The homogenized sludge samples collected from different digesters were harvested by centrifugation $(120 \times 100 \mathrm{~g}$ for $10 \mathrm{~min}$ at $4^{\circ} \mathrm{C}$ ). Then the samples were washed twice with phosphate-buffered saline (PBS [130 $\mathrm{mM} \mathrm{NaCl}, 10 \mathrm{mM} \mathrm{NaHPO} 4, \mathrm{pH}$ 7.2]) and settled for $2 \mathrm{~h}$. After that the samples were then fixed with $4 \%$ paraformaldehyde in PBS for $6 \mathrm{~h}$ at $4^{\circ} \mathrm{C}$, before being exposed to $50 \%$ ethanol in PBS for $12 \mathrm{~h}$ at $4^{\circ} \mathrm{C}$. Five freeze-thaw cycles $\left(-80^{\circ} \mathrm{C}\right.$ to $\left.60^{\circ} \mathrm{C}\right)$ were done after fixation to allow probes to penetrate the cells in the sludge samples. Next, the samples were dehydrated by successive passages through $50 \%, 80 \%$, and $100 \%$ ethanol for three times, 50:50 (v/v) ethano-xylene, and 100\% xylene for three times, and dried at room temperature for FISH. Hybridization steps were performed at $46^{\circ} \mathrm{C}$ for $1.5 \mathrm{~h}$ with buffer $(0.9 \mathrm{M} \mathrm{NaCl}, 20 \mathrm{mM}$ Tris- $\mathrm{HCl}$ [pH 7.2], 0.01 sodium dodecyl sulfate and $35 \%$ formamide) containing $50 \mathrm{ng}$ probe per microliter and then washed 
with buffer $\left(15 \mathrm{~min}\right.$ at $\left.48^{\circ} \mathrm{C}\right)$. A fluorescein isothiocyanate (FITC)-labeled EUB338mix probe with a sequence of 5'-GCTGCCTCCCGTAGGAGT-3' was used to target Bacteria (green) ${ }^{23}$. A cyanine 3 (cy3)-labeled P932 probe with a sequence of 5'-GATYYGCGATTACTAGYAACTC-3' was used to target Clostridium species of clusters I and XI (red), the ethanol-producing Fe(III)-reducing species detected in this study.

Table S1. A simple conclusion of fermentation products ranging with $\mathrm{pH}$ during anaerobic digestion.

\begin{tabular}{ccccc}
\hline $\mathbf{p H}$ & Ethanol & Acetate & Propionate & Butyrate \\
\hline $6.0-6.5$ & - & ++ & + & +++ \\
$5.0-6.0$ & - & ++ & +++ & + \\
$4.5-5.0$ & ++ & ++ & + & ++ \\
$4.0-4.5$ & +++ & ++ & + & + \\
$3.0-4.0$ & + & + & - & - \\
$<3.0$ & - & - & - & - \\
\hline
\end{tabular}

Note: The number of ' + ' represents the relative intensity of fermentation products.

The symbol '-' represents no production. 


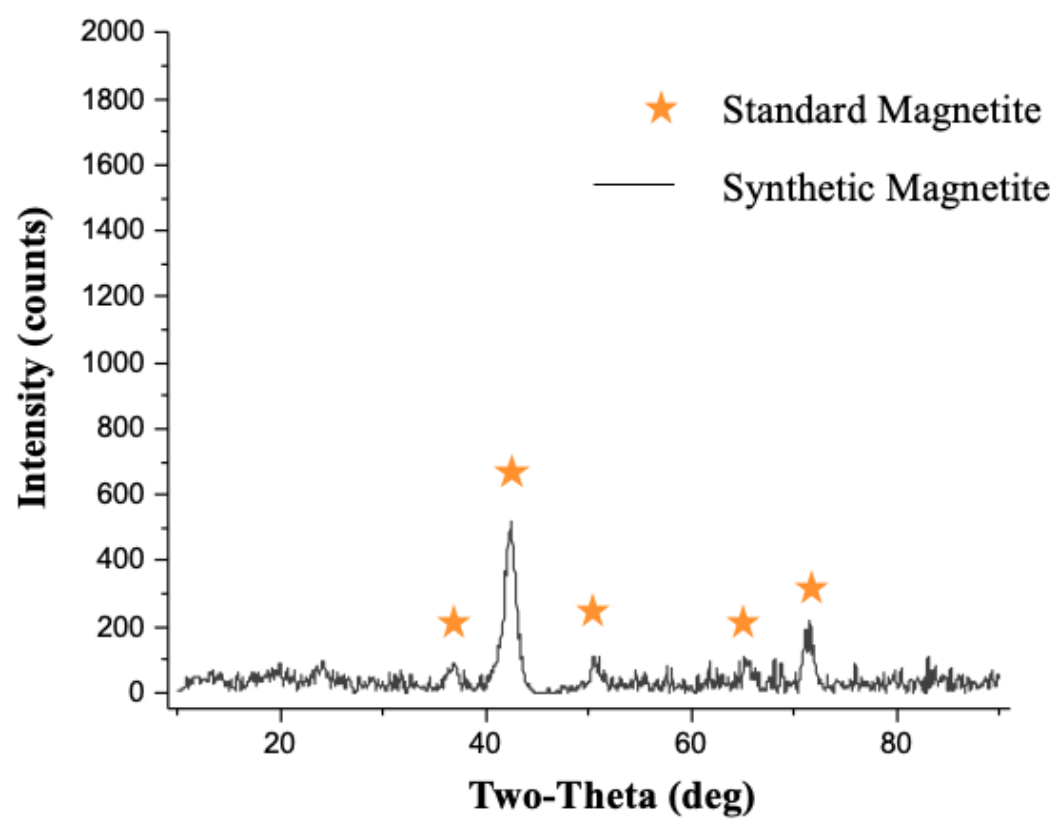

Figure S1. XRD diffraction patterns of the synthesis of magnetite and standard magnetite.

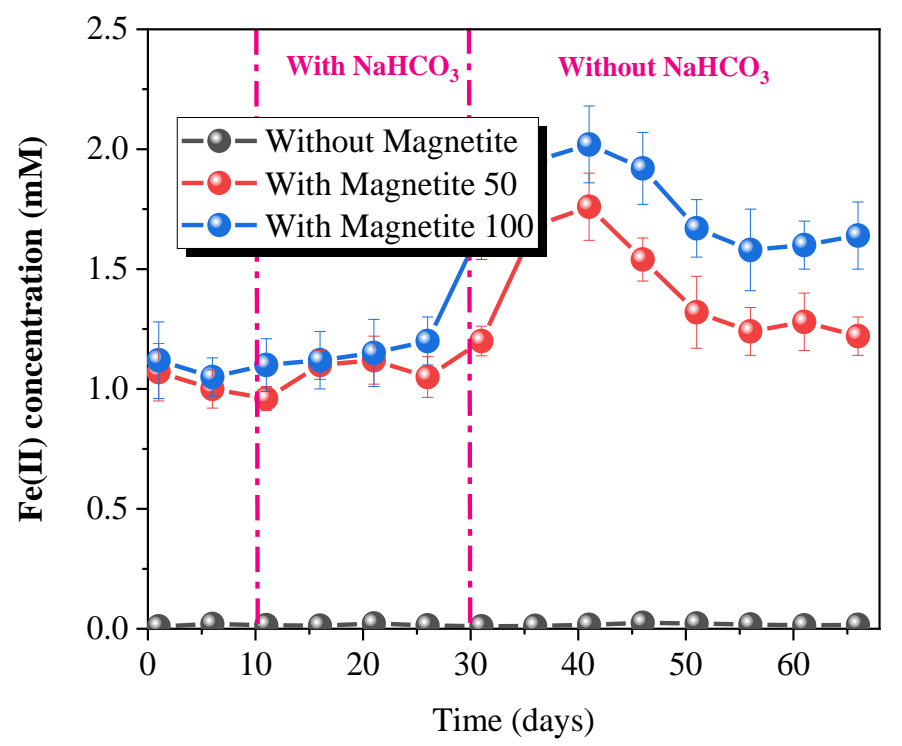

Figure S2. Effluent concentration of $\mathrm{Fe}(\mathrm{II})$ in the anaerobic digesters during the 65-day experiments. Error bars represent standard deviations of the three-group parallel measurements. 